\title{
Preliminary Phytochemical screening and Biological Activities of Adina cardifolia
}

\author{
Ved Prakash1, Sarika Saxena ${ }^{1 *}$, Savita Gupta ${ }^{1}$, Ashish Kumar Saxena ${ }^{2}$, Rajkumar Yadav ${ }^{1}$, Sunil Kumar Singh $^{3}$ \\ ${ }^{1}$ Madhav Institute of Technology and Science, Gwalior (M.P.), India \\ ${ }^{2} \mathrm{CHC}$, Rampaili, Dist. Balaghat, India \\ ${ }^{3}$ VIT University, Vellore Tamil Nadu, India
}

\begin{abstract}
Adina cordifolia leaf was investigated for its phytochemical screening and antioxidant activity. The plant extracts were screened for presence of flavonoids, carbohydrate, alkaloid, saponin, phenol, tannins, phlobatannins, terpenoids, cardiac glycosides. Total flavonoid content, phenols content was estimated. Antioxidant activity was determined using nitric oxide scavenging assay, DPPH assay, hydrogen peroxide scavenging and ferric reducing methods, also MIC was calculated against a set of bacteria (S. aureus, B. subtilis, E. coli, K. pneumonia).
\end{abstract}

Keywords: Adina cardifolia; Phytochemical; Antioxidant; MIC.

\section{Introduction}

Medicinal plants contain some organic compounds which provide definite physiological action on the human body and these bioactive substances include tannins, alkaloids, carbohydrates, terpenoids, steroids and flavonoids [1]. Awareness of medicinal plants usage is a result of the many years of struggles against illnesses due to which man learned to pursue drugs in barks, seeds, fruit bodies, and other parts of the plants [2]. The knowledge of the development of ideas related to the usage of medicinal plants as well as the evolution of awareness has increased the ability of pharmacists and physicians to respond to the challenges that have emerged with the spreading of professional services in facilitation of man's life [3]. Among the 7,000 species of medicinal plants recognized all over the world. The medicinal value of plants lies in some chemical substances that produce a definite physiologic action on the human body [4]. The most important of these bioactive compounds of plants are alkaloids, flavonoids, tannins and phenolic compounds. The phytochemical research based on ethno-pharmacological information is generally considered an effective approach in the discovery of new anti-infective agents from higher plant [5]. Scientists estimate that there may be as many as 10,000 different phytochemicals having the potential to affect diseases such as cancer, stroke metabolic syndrome [6]. Plants are rich in a wide variety of secondary metabolite such as tannins, terpenoids, alkaloids, and flavonoids which have been proved in vitro to have anti microbial properties. The use of plant extracts and phytochemical, both with known antimicrobial properties, can be of great significance in therapeutic treatments [7].

Adina cordifolia is a moderate sized deciduous tree grows up to 35 $\mathrm{m}$ in height. Leaves large, cordate and abruptly acuminate. Flowers yellow in globose pedunculate heads; fruits capsules, splitting into two dehiscent cocci, seeds many, narrow, small, and tailed.

$\begin{array}{ll}\text { Class: } & \text { Magnoliopsida } \\ \text { Sub-class: } & \text { Asteridae } \\ \text { Super order: } & \text { Gentiananae } \\ \text { Order: } & \text { Gentianales } \\ \text { Family: } & \text { Rubiaceae } \\ \text { Subfamily: } & \text { Cinchonoideae }\end{array}$

Genus: Adina

Specific epithet: cardifolia

Botanical name: Adina cardifolia

\section{Material and Methods}

\section{Collection of plant sample}

The plant leaves of Adina cordifolia were collected from upvan field Gwalior. It was processed and analyzed.

\section{Preparation of plant extracts}

The plant leaves were air dried at room temperature $\left(30^{\circ} \mathrm{C}\right)$ for two weeks which it was grinded to the uniform powder and this powder was used for preparation of different extracts.

\section{Preparation of different extract using different solution of air dried powder of Adina cardifolia}

The extract of leaf sample is prepared by using soxhlet apparatus. 10 $\mathrm{g}$ of air dried powder in $100 \mathrm{ml}$ of desire solution. This apparatus work on higher temperature with evaporation process. Extract preparation by soxhlet apparatus used for 12 hour continuously for each solution. The extracts are then filtered using filter paper.

\section{Phytochemical analysis}

Qualitative assay, for the presence of plant primary and secondary metabolites such as carbohydrate, reducing sugar, saponin, glycosides, tannins, flavonoids and alkaloids were carried out on the extract of the Adina cordifolia leaves. The presence or absence of the phytochemical constituents of material was analyzed using the following standard methods [8].

*Corresponding author: Sarika Saxena, Madhav Institute of Technology and Science, Gwalior (M.P.), India, E-mail: saxena.sarika5@gmail.com

Received January 06, 2015; Accepted January 30, 2015; Published February 07, 2015

Citation: Prakash V, Saxena S, Gupta S, Saxena AK, Yadav R, et al. (2015) Preliminary Phytochemical screening and Biological Activities of Adina cardifolia. J Microb Biochem Technol 7: 033-032. doi:10.4172/1948-5948.1000178

Copyright: ( 2015 Prakash V, et al. This is an open-access article distributed under the terms of the Creative Commons Attribution License, which permits unrestricted use, distribution, and reproduction in any medium, provided the original author and source are credited 


\section{Test for flavonoids}

Test solution when treated with few drops of ferric chloride solution would result in the formation of blackish red color indicating the presence of flavonoids [9].

\section{Test for carbohydrates}

Benedict's test-Test solution was mixed with few drops of Benedict's reagent (alkaline solution containing cupric citrate complex) and boiled in water bath, observed for the formation of reddish brown precipitate to show a positive result for the presence of carbohydrate [10].

\section{Test for Alkaloids}

One milliliter of aqueous extract was stirred and placed in $1 \%$ aqueous hydrochloric acid on a steam bath, Then, $1 \mathrm{~mL}$ of the filtrate was treated with Dragedorff's reagent. Turbidity or precipitation with this reagent was considered as evidence for the presence of alkaloids [11].

\section{Test for Saponin}

About $2 \mathrm{~g}$ of the powdered sample was boiled in $20 \mathrm{ml}$ of distilled water in a water bath and filtered. $10 \mathrm{ml}$ of the filtrate was mixed with 5 $\mathrm{ml}$ of distilled water and shaken vigorously for a stable persistent froth. The frothing was mixed with 3 drops of olive oil and shaken vigorously, then observed for the formation of emulsion [12].

\section{Test for Phenols}

$5 \mathrm{ml}$ of Folin Ciocalteu reagent and $4 \mathrm{ml}$ of aqueous sodium carbonate were added to $0.5 \mathrm{ml}$ of extract. Appearance of blue color indicates the presence of phenols.

\section{Test for Tannins}

About $0.5 \mathrm{~g}$ of the extract was boiled in $10 \mathrm{ml}$ of water in a test tube and then filtered. A few drops of $0.1 \%$ ferric chloride was added and observed for brownish green or a blue-black colouration [13].

\section{Test for Phlobatannins}

Fruit extracts were boiled with $1 \%$ aqueous Hydrochloric acid. Formation of red precipitate indicates the presence of phlobatanins.

\section{Test for Terpenoids}

$5 \mathrm{ml}$ of each extract were mixed in $2 \mathrm{ml}$ of Chloroform and 3 $\mathrm{ml}$ Concentrated sulphuric acid was carefully added to form a layer. A reddish brown colour at the interface indicates the presence of terpenoids [14].

\section{Test for Cardiac glycosides}

$5 \mathrm{ml}$ of each extract was treated with $2 \mathrm{ml}$ of glacial acetic acid containing one drop of Ferric chloride solution. This was layered with $1 \mathrm{ml}$ of concentrated sulphuric acid. A brown ring at the interface indicates the presence of a deoxysugar which is characteristics of cardenolides. A violet ring may appear below the brown ring, while in the acetic acid layer, a greenish ring may form just spreading gradually throughout the layer [14].

\section{Determination of total flavonoids content assay}

About $10 \mathrm{~g}$ of the plant sample was extracted repeatedly with $100 \mathrm{ml}$ of aqueous, methanol, ethanol, petroleum ether, chloroform, benzene ( $80 \%$ accept water) at room temperature. The whole solution was filtered through Whatman filter. The filtrate was later transferred into a crucible and evaporated into dryness over a water bath; the dry content was weighed to a constant weight [15].

\section{Determination of total phenols content assay}

Total phenols were determined by Folin Ciocalteu reagent. $5 \mathrm{ml}$ of Folin Ciocalteu reagent and $4 \mathrm{ml}$ of aqueous Sodium carbonate were added to $0.5 \mathrm{ml}$ of extract. After $15 \mathrm{~min}$. of incubation at room temperature, the absorbance was read at $765 \mathrm{~nm}$. The standard curve was prepared using Gallic acid. Total phenols were expressed in terms of Gallic acid equivalents (mg CAE/100 g FW) [8].

\section{Determination of nitric oxide scavenging activity assay}

Nitric oxide scavenging activity was measured by the spectrophotometry method [16]. Sodium nitroprusside $(5 \mathrm{mmol})$ in phosphate buffered saline was mixed with a control without the test compound. Test solutions at different concentrations $(7.8-1000 \mu \mathrm{g} / \mathrm{ml})$ were dissolved in methanol and incubated at $25^{\circ} \mathrm{C}$ for $30 \mathrm{~min}$. After $30 \mathrm{~min}, 1.5 \mathrm{ml}$ of the incubated solution was removed and diluted with $1.5 \mathrm{ml}$ of Griess reagent (1\% Sulphanilamide, 2\% Phosphoric acid, and $0.1 \%$ Naphthyl ethylenediamine dihydrochloriode). The absorbance of the chromophores formed during the subsequent coupling with Naphthyl ethylenediamine dihydrochloriode was measured at $546 \mathrm{~nm}$ (Oyaizu M., 1986).

Inhibition of nitric oxide free radical in percentage was calculated by the formula:

$$
\text { Inhibition }(\%)=\left[\left(\mathrm{A}_{\text {control }}-\mathrm{A}_{\text {test }}\right) / \mathrm{A}_{\text {control }}\right] \times 100
$$

Where $\mathrm{A}_{\text {control }}$ is the absorbance of the control (solution without extract) and $\mathrm{A}_{\text {test }}$ is the absorbance of samples (extract and ascorbic acid).

\section{Determination of 1, 1-diphenyl-2-picrylhydrazyl (DPPH) scavenging activity assay}

DPPH assay was carried out as described by Hsu et al. [17]. with some modifications. $1.5 \mathrm{ml}$ of $0.1 \mathrm{mM}$ DPPH solution was mixed with $1.5 \mathrm{ml}$ of various concentrations ( 10 to $500 \mu \mathrm{g} / \mathrm{ml}$ ) of leaf extract. The mixture was shaken vigorously and incubated at room temperature for $30 \mathrm{~min}$ in the dark. The reduction of the DPPH free radical was measured by reading the absorbance at $517 \mathrm{~nm}$ by a spectrophotometer. The solution without any extract and with DPPH and methanol was used as control.

The experiment was replicated in three independent assays. Ascorbic acid was used as positive controls. Inhibition of DPPH free radical in percentage was calculated by the formula:

$$
\text { Inhibition }(\%)=\left[\left(\mathrm{A}_{\text {control }}-\mathrm{A}_{\text {test }}\right) / \mathrm{A}_{\text {control }}\right] \times 100
$$

Where $A_{\text {control }}$ is the absorbance of the control (solution without extract) and $\mathrm{A}_{\text {test }}$ is the absorbance of samples (extract and ascorbic acid).

\section{Determination of Hydrogen Peroxide scavenging activity Assay}

The ability of the Adina cardifolia extracts to scavenge hydrogen peroxide was determined according to the method of A solution of hydrogen peroxide $(40 \mathrm{mM})$ was prepared in phosphate buffer $(\mathrm{pH}$ 7.4). Extracts $(100 \mu \mathrm{g} / \mathrm{mL})$ in distilled water were added to a hydrogen peroxide solution $(0.6 \mathrm{~mL}, 40 \mathrm{mM})$. Absorbance of hydrogen peroxide at $230 \mathrm{~nm}$ was determined 10 minutes later against a blank solution 
Citation: Prakash V, Saxena S, Gupta S, Saxena AK, Yadav R, et al. (2015) Preliminary Phytochemical screening and Biological Activities of Adina cardifolia. J Microb Biochem Technol 7: 033-032. doi:10.4172/1948-5948.1000178

containing the phosphate buffer without hydrogen peroxide[18].

The percentage of hydrogen peroxide scavenging of both Adina Cardifolia extracts and Ascorbic acid standard compounds were calculated:

\section{Inhibition $(\%)=[($ Acontrol-Atest $) /$ Acontrol $] . \times 100$}

Where $A_{\text {control }}$ is the absorbance of the control (solution without extract) and $\mathrm{A}_{\text {test }}$ is the absorbance of samples (extract and ascorbic acid).

\section{Determination of ferric Reducing antioxidant Assay}

Different concentrations of plant extracts (200 - $1200 \mathrm{ppm})$ in $1 \mathrm{ml}$ of distilled water were mixed with phosphate buffer $(2.5 \mathrm{ml}, 0.2 \mathrm{M}, \mathrm{pH}$ $6.6)$ and potassium ferricyanide $[\mathrm{K} 3 \mathrm{Fe}(\mathrm{CN}) 6] .(2.5 \mathrm{ml}, 1 \%)$. The mixture was incubated at $50 \mathrm{oC}$ for $20 \mathrm{~min}$. Then, $2.5 \mathrm{ml}$ of trichloroacetic acid (10\%) was added to mixture, which was then centrifuged for $10 \mathrm{~min}$ at $3000 \mathrm{rpm}$. The upper layer of solution $(2.5 \mathrm{ml})$ was mixed with distilled water $(2.5 \mathrm{ml})$ and $\mathrm{FeCl} 3(0.5 \mathrm{ml}, 0.1 \%)[19]$.

The absorbance was measured at $700 \mathrm{~nm}$ against a blank using UVVis spectrophotometer. Increased absorbance of the reaction mixture indicates increase in reducing power.

\section{Determination of Minimum Inhibitory Concentration (MIC)}

Minimum inhibitory concentration was carried out on sensitive extracts. four test tubes were used for each organism. Broth dilution method was used. $9 \mathrm{ml}$ of nutrient broth was dispensed into each of the four test tubes used per organism. The test tubes were autoclaved at $121^{\circ} \mathrm{C}$ for 15 minutes and allowed to cool and properly labeled. One milliliter of reconstituted extract, prepared by dissolving $1 \mathrm{ml}$ extract in $10 \mathrm{ml}$ solution, was dispensed into the first test tube and shaken. Form the first test tube, $1 \mathrm{ml}$ of the mixture was taken and dispensed into the second and shaken. This was repeated for the rest of the test tubes. From the last test tube, $1 \mathrm{ml}$ was discarded. This dilution was carried out for all viable extracts, giving rise to $10,000,1,000,100$, and $10 \mathrm{mg} /$ $\mathrm{ml}$ of extracts respectively in the test tubes. The test tubes were then inoculated with test organisms using a sterile wire loop. The fifth test tube was not inoculated and serves as a control. After inoculation, the test tubes were properly sealed and incubated for 24 hours. They were observed for turbidity (growth of organism). The test tube with least concentration which showed no turbidity indicates the MIC [20].

\section{Results}

The extraction of leaf powder was done in six different solvents viz., Ethanol, Methanol, Petroleum ether, Benzene, Chloroform and Water. The different extracts of plant have been investigated for their antioxidant activity, Photochemical and antimicrobial activity.

\section{Qualitative phytochemical analysis}

The phytochemical characteristic of plant tested was summarized in the Table 1 . The result revealed the presence of medically active compound in the plant studied. From the table, it could be seen that, Alkaloid, Flavonoids, Phenolic, Saponin, Tannin etc. were present in all the different extract of A.Cardifolia

The preliminary phytochemical analysis showed presence of Alkaloid, Flavonoids, Phenolic, Saponin, Tannin, Steroids. However, all these chemical were not extractable in one solvent. Alkaloid, Flavonoids, Phenolic, Saponin, Tannin, Steroids were present in ethanol, methanol, water Extract weak presence in Petroleum ether,

\begin{tabular}{|l|c|c|c|c|c|c|}
\hline Phytochemicals & Ethanol & Methanol & $\begin{array}{c}\text { Petroleum } \\
\text { ether }\end{array}$ & Benzene & Chloroform & Water \\
\hline Flavonoid & +++ & +++ & + & + & ++ & ++ \\
\hline Carbohydrate & +++ & +++ & ++ & + & + & +++ \\
\hline Alkaloid & +++ & ++ & + & + & + & ++ \\
\hline Saponin & +++ & +++ & ++ & ++ & ++ & +++ \\
\hline Phenols & +++ & ++ & + & + & + & ++ \\
\hline Tannin & +++ & +++ & ++ & + & ++ & +++ \\
\hline Phlobatannin & ++ & + & - & - & - & + \\
\hline Terpenoid & +++ & +++ & ++ & ++ & + & +++ \\
\hline Cardiacglycoside & - & - & - & - & - & - \\
\hline
\end{tabular}

Where +++ shows strong presence, ++ shows partially strong, + shows week and - shows absence of phytochemical activities.

Table 1: Phytochemical screening of crude extracts of $A$. cardifolia.

\begin{tabular}{|c|c|c|c|c|c|}
\hline \multirow{2}{*}{$\begin{array}{l}\text { Adina } \\
\text { cardifolia } \\
\text { leaves }\end{array}$} & \multirow[t]{2}{*}{ Extract } & \multicolumn{4}{|c|}{ Minimum inhibitory concentration (MIC) $(\mathrm{mg} / \mathrm{ml})$} \\
\hline & & S. aureus & B. subtilis & E. coli & K. pneumonia \\
\hline & Ethanol & 0.76 & 0.78 & 0.88 & 0.91 \\
\hline & Methanol & 0.98 & 0.90 & 0.79 & 0.82 \\
\hline & Chloroform & 1.42 & 1.38 & 1.52 & 1.59 \\
\hline & Benzene & 2.32 & 2.87 & 3.30 & 3.10 \\
\hline & Petroleum ether & 1.58 & 1.33 & 1.35 & 1.13 \\
\hline & Water & 1.12 & 1.30 & 1.10 & 1.96 \\
\hline & $\begin{array}{l}\text { Ampicillin } \\
\text { ( } \mu \mathrm{g} / \mathrm{ml}) \text { Positive } \\
\text { Control }\end{array}$ & 0.188 & 0.170 & 0.211 & 0.230 \\
\hline
\end{tabular}

Table 2: Minimum Inhibitory Concentration (MIC) ( $\mathrm{mg} / \mathrm{ml})$ of Adina cardifolia leaves extracts.

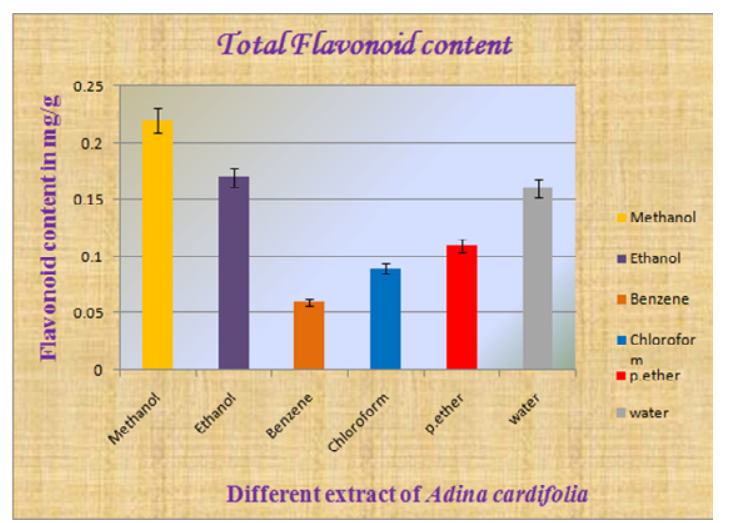

Graph 1: Total flavonoids content in the various extract of $A$. cardifolia.

Benzene, Chloroform. Tannin was found almost strong in each extract (Table 2).

\section{Determination of total flavonoid content}

Total flavonoids content of Adina cordifolia showed maximum flavonoids content of Adina cardifoliawas found to be $0.22 \mathrm{mg} / \mathrm{g}$ in Methanol.

\section{Determination of total phenolic content}

Total phenolic content of Adina cordifolia in different solvent was observed which showed ethanolic extract contains nearly more phenolic content then other extract. Graph 1 show that ethanol extract contains high amount of phenols $(0.274 \mathrm{mg} / \mathrm{gram})$ while methanol contains $(0.254 \mathrm{mg} / \mathrm{gram})$, aqueous extract contain $(0.22 \mathrm{mg} / \mathrm{gram})$, 
and benzene had lower phenolic content only with $(0.132 \mathrm{mg} / \mathrm{gram})$. These phytochemical protect the cells from oxidative damage caused by free radicals.

\section{Determination of Nitric oxide scavenging activity}

The scavenging of NO was found to increase in dose dependent manner. The extracts showed weak nitric oxide-scavenging activity at low concentration as in at 100 and $200 \mu \mathrm{g} / \mathrm{ml}$. Maximum inhibition of $\mathrm{NO}$ was observed in the extracts of chloroform at highest concentration $(500 \mathrm{mg} / \mathrm{ml})$ for the sample. At this maximum concentration, inhibition was found to be $70.66 \%$ for ascorbic acid, which serves as the standard. For dry leaf extract, inhibition was found to be higher $57.35 \%$ for the sample. At $500 \mathrm{mg} / \mathrm{ml}$ other solution extract found $56.15 \%$ in methanol, $49.45 \%$ in ethanol, $52.1 \%$ in Petroleum ether, $51.32 \%$ in water and $50.15 \%$ in benzene respectively. As shown in Graph 2.

\section{Determination of DPPH scavenging activity}

DPPH radical scavenging activity of dry leaf extract of Adina cordifolia was compared with Ascorbic acid. At a concentration of $500(\mu \mathrm{g} / \mathrm{ml})$, the scavenging activity of ethanol extract of Adina cordifolia reached $59.33 \%$, while at the same concentration; the standard was $72.56 \%$. At $500 \mu \mathrm{g} / \mathrm{ml}$ other solution extract found $51.23 \%$ in methanol, $49.36 \%$ in Water, $43.25 \%$ in Petroleum ether, $44.25 \%$ in chloroform and $38.59 \%$ in benzene respectively as shown in Graph 3

\section{Determination of Hydrogen peroxide scavenging activity}

Adina cordifolia leaf extract scavenged hydrogen peroxide which

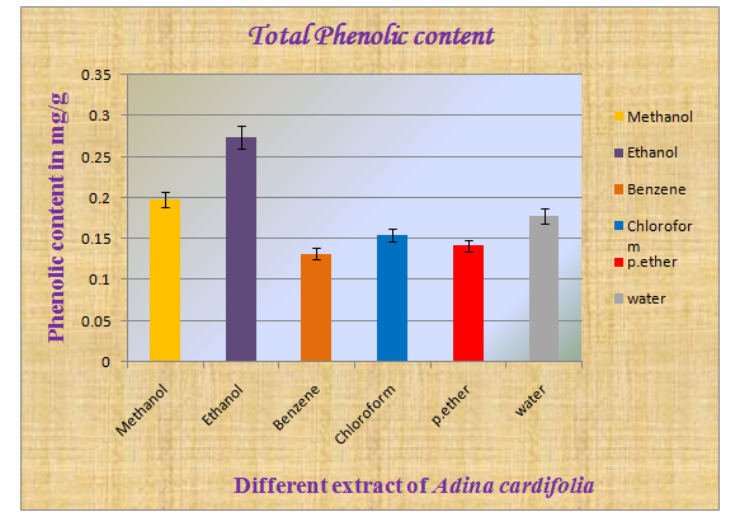

Graph 2: Total phenol content in the various extract of $A$. cardifolia.

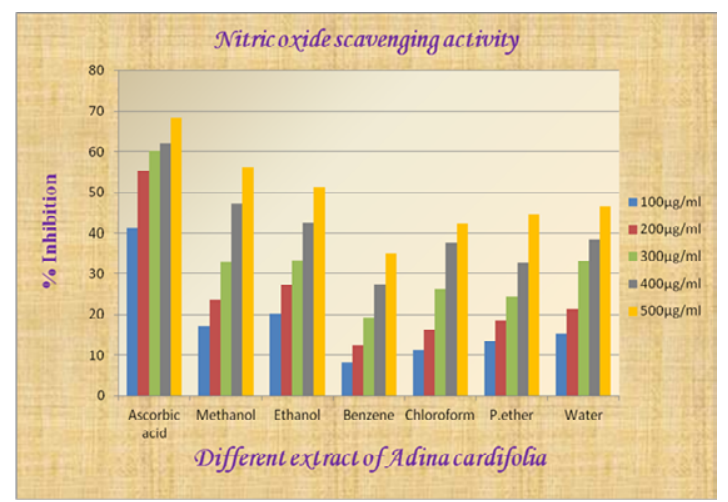

Graph 3: Nitric oxide scavenging activity in the various extract of A. cardifolia.

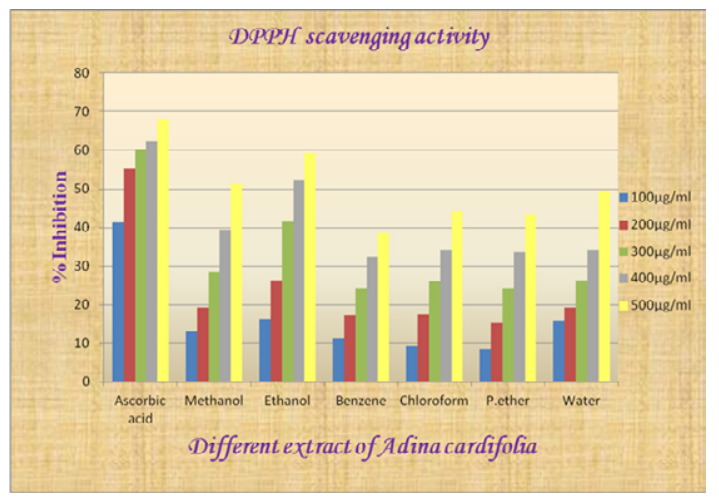

Graph 4: DPPH scavenging activity in the various extract of $A$ cardifolia.

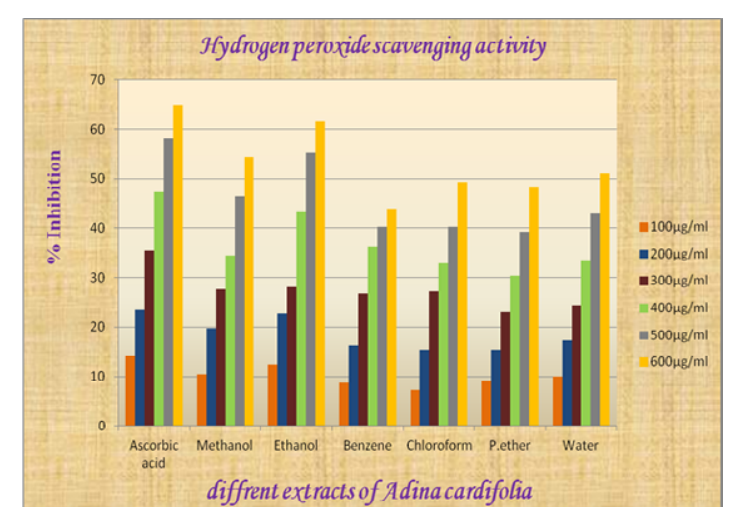

Graph 5: Hydrogen peroxide scavenging activity in the various extract of $A$. cardifolia.

may be attributed the presence of phenolic group. The scavenging of $\mathrm{H}_{2} \mathrm{O}_{2}$ was found to increase in dose dependent manner. Maximum inhibition of $\mathrm{H}_{2} \mathrm{O}_{2}$ was observed in the extracts of Ethanol at highest concentration $(600 \mu \mathrm{g} / \mathrm{ml})$ for the sample. At this maximum concentration, inhibition was found to be $61.47 \%$ in ethanolic extract of dry leaf whereas ascorbic acid inhibited more. At $600 \mu \mathrm{g} / \mathrm{ml}$ other solution extract found $50.36 \%$ in methanol, $60.9 \%$ in Water, $56.02 \%$ in Petroleum ether, $48.65 \%$ in chloroform and $43.9 \%$ in benzene respectively. As shown in Graph 4-7.

\section{Determination of ferric Reducing antioxidant power activity}

Data show that all the samples increased their reducing ability when the concentration of extracts was increased. At $200 \mathrm{ppm}$, ethanol extract had the highest ability to reduce Fe (III) and had no significant difference with other different solution extract. At 1200 ppm, Ethanol extract have higher ability than other to reduce Fe (III) to Fe (II). At $1200 \mathrm{ppm}$ methanol extract showed higher absorbance. After it ethanol, water, petroleum ether, benzene, chloroform respectively.

\section{Determination of Minimum Inhibitory Concentration (MIC)}

The MIC was evaluated on plant extracts that showed antimicrobial activity. The minimum inhibitory concentration (MIC) values obtained for extracts against the bacterial strains varied from plant extract to the other.

All the plant extracts showed antimicrobial activity in regards to 


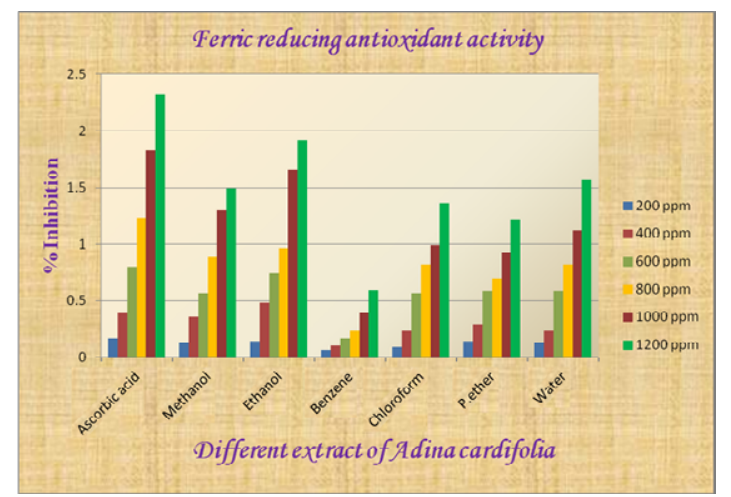

Graph 6: Ferric reducing scavenging activity in the various extract of $A$. cardifolia.

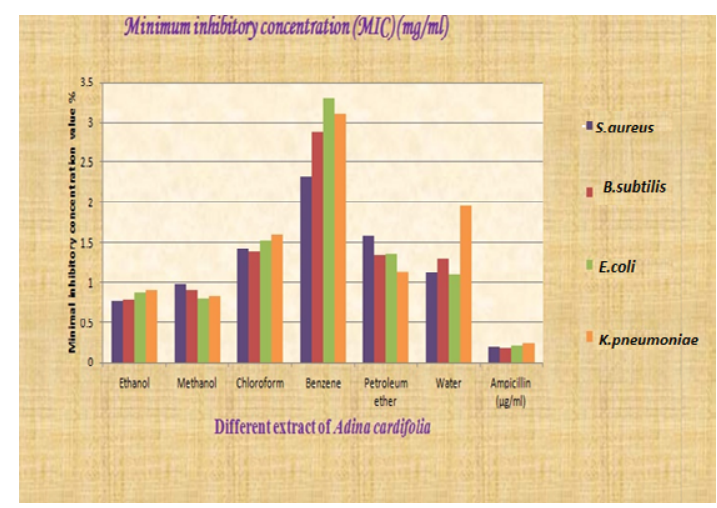

Graph 7: Minimum Inhibitory Concentration (MIC) (mg/ml) of Adina cardifolia leaves extracts.

at least three microorganisms tested. The ethanol extracts of Adina cordifolia were the most active against the microorganisms studied. This possibly means that the compound responsible for the antimicrobial activity was present in each extract at a different concentration.

Ethanol extracts exhibited a higher degree of antimicrobial activity as compared with water and other extract fractions. This finding is correlated with the medicinal preparations that use rum and liquor to extract the active plant components. For instance, MIC values of 0.76 , $0.78,0.88$, and $0.91 \mathrm{mg} / \mathrm{ml}$ were obtained for ethanolic extracts of A.cardifolia.

The strongest activity (MIC $0.76 \mathrm{mg} / \mathrm{mL}$ ) was observed in the ethnolic extracts of $A$. cordifolia (leaves), Benzene extract of $A$. cordifolia (leaves) was the least active, showing an MIC of $3.30 \mathrm{mg} / \mathrm{mL}$.

\section{Conclusion}

The results revealed the presence of medicinally important constituents in the plants studied. Many evidences gathered in earlier studies which confirmed the identified phytochemicals to be bioactive. Several studies confirmed the presence of these phytochemicals contribute medicinal as well as physiological properties to the plants studied in the treatment of different ailments. Therefore, extracts of dry leaf powder of Adina cordifolia plant could be seen as a good source for useful drugs. This study was designed to investigate the phytochemical characterization and evaluate the in vitro antioxidant activity of Adina cordifolia which was used as a antiulcer, anti-inflammatory in Ayurveda remedies. To conclude, the above experiments clearly indicate that different extract of dry leaf powder of Adina cardifolia showed effective free radical scavenging activity which can be attributed to the presence of Flavonoids, Tannin and phenolics along with other compounds. Phenolic compounds, flavonoids and other secondary metabolites were detected in 6 different extract. Ethanolic, aqueous and methanolic extract showed the powerful result of containing phenolics, flavonoids and scavenging activity. Same these extract of Adina cordifolia had shown the effective antimicrobial activity for four different bacterial strains. The traditional medicine practice is recommended strongly for these plants as well as it is suggested that further work should be carried out to isolate, purify, and characterize the active constituents responsible for the activity of these plants. Also additional work is encouraged to elucidate the possible mechanism of action of these extracts. Further investigations on the different extract of dry leaf powder of Adina cardifolia purification of compounds and molecular mechanisms of its protective actions will be performed.

\section{References}

1. Ghani A (1998) "Medicinal plants of Bangladesh with chemical constituents and uses" Asiatic Society of Bangladesh, Dhaka. 11: 236-244.

2. Tiwari A (2001) "Imbalance in antioxidant defence and hillian diseases: Multiple approach of natural antioxidants therapy" Curro Sci 81: 1179-1187.

3. Prasad PV, Subhaktha PK, Narayana A (1998) "Medico-historical study of asvattha" J Contenantal. 15: 288-296.

4. Sivarajan VV, Balachandean I (1999) "Ayurvedic Drugs and their plants sources. New Delhi" Oxford and IBH publishing Co. Pvt. Ltd. 96-121.

5. Farnsworth NR, Henry LK, Svoboda GH, Blomster RN, Yates MJ, et al. (1966) "Biological and phytochemical evaluation of plants". J Lloydia 29: 113-122

6. Singh SS, Pandey SC, Srivastava S, Gupta KS, Patro B, et al. (2003) "Chemistry and medicinal properties of Tinospora cardifolia (Guduchi)" Indian J Pharmacol 35: 83-91.

7. Gislene GF, Nascimento, Juliana Locatelli, Freitas PC, Silva GL (2000) "antimicrobial activity of some Brazilian plant" Brazilian Journal of Microbiology 31: $247-256$

8. Harborne JB (1973) Phytochemical methods, London. Chapman and Hall, Ltd. pp. 49-188.

9. Bhandary SK, Kumari NS, Bhat VS, Sharmila KP, Bekal MP (2012) Preliminary phytochemical screening of various extracts of Punica granatum peel, whole fruit and seeds. J Health Sci, 2: 35-38.

10. Yadav RNS, Agarwala M (2011) Phytochemical analysis of some medicina plants. Journal of phytology, 3.

11. Tadhani M, Subhash R (2006) Preliminary studies on Stevia rebaudiana leaves: proximal composition, mineral analysis and phytochemical screening J Med Sci 6: 321-326.

12. Edeoga HO, Okwu DE, Mbaebie BO (2005) Phytochemical constituents of some Nigerian medicinal plants. African journal of biotechnology, 4: 685-688.

13. Ayoola GA, Coker HA, Adesegun SA, Adepoju-Bello AA, Obaweya K, et al (2008) Phytochemical screening and antioxidant activities of some selected medicinal plants used for malaria therapy in Southwestern Nigeria. Tropical Journal of Pharmaceutical Research, 7: 1019-1024.

14. Singh MP, Saxena S (2011) Phytochemical analysis and antimicrobial efficacy of methanolic extract of some medicinal plants at Gwalior region. Journal of Pharmacy Research, 4.

15. Harbone JB, Baxter H (1999) "Eds: The handbook of natural flavonoids" John Wiley and sons, Chichester 1: 24-44

16. Madan MP, Raghvan G, Ajay KSR, Prabhu P (2005) "Free radical scavenging potential of Saussarea costus" Acta Pharm. 55: 297-304.

17. Hsu JK, Chen D, Chang F (2007) "Antioxidant activity of plant" Toxicology. 55:299-308.

18. Ruch D, Holke JK, Wurtele ES (1982) "Antioxidant activity of plants phytochemicals to hydroxyl radical" J Phytochemistry. 28: 82-91. 
Citation: Prakash V, Saxena S, Gupta S, Saxena AK, Yadav R, et al. (2015) Preliminary Phytochemical screening and Biological Activities of Adina cardifolia. J Microb Biochem Technol 7: 033-032. doi:10.4172/1948-5948.1000178

19. Oyaizu M (1986) Studies on products of browning reaction--antioxidative activities of products of browning reaction prepared from glucosamine. Eiyogaku zasshi Japanese journal of nutrition.
20. Tshesche $R$ (1970) "Advances in the chemistry of antibiotics substances from higher plants: Pharmacogency and phytochemistry. In: proceddings of the 1st international congress, Murich" Edited by: Wagner H. Horharmmer L. springerVerlag, Berlin Heidelberg, New York. 274-289. 